\title{
Unusual Record For Greater Bulldog Bat Noctilio leporinus Linnaeus, 1758 (Chiroptera: Noctilionidae) in the Southern Andes of Ecuador
}

\author{
Carlos Nivelo-Villavicencio ${ }^{1,3 *}$, Francisco Sánchez-Karste ${ }^{2}$, David C. Siddons ${ }^{3}$, Javier Fernández de Córdova ${ }^{4}$ \\ ${ }^{1}$ Museo de Zoología de la Universidad del Azuay. Escuela de Biología, Ecología y Gestión, \\ Universidad del Azuay, Av. 24 de mayo 7-77 y Hernán Malo, Teléfono: (593) 7 4091000, Fax: (593) \\ 72815-997, Apartado 01.01.981, Cuenca, Ecuador. \\ 2 Programa de biodiversidad, Parque Nacional Cajas, Subgerencia de Gestión Ambiental - ETAPA \\ EP., 010150, Cuenca-Ecuador. \\ ${ }^{3}$ Laboratorio de Ecología Acústica, Escuela de Biología Ecología y Gestión, Universidad del Azuay, \\ Av. 24 de mayo 7-77 y Hernán Malo, Teléfono: (593) 7 4091000, Fax: (593) 72815-997, Apartado \\ 01.01.981, Cuenca, Ecuador. \\ ${ }^{4}$ Facultad de Ciencias Exactas y Naturales, Universidad de Buenos Aires. Intendente Güiraldes \\ 2160 Ciudad Universitaria, Apartado C1428EGA, Argentina. \\ * Autor para Correspondencia / Corresponding Author, e-mail: cvillavicencio@uazuay.edu.ec
}

\section{Registro inusual para el murciélago Pescador Mayor Noctilio leporinus Linnaeus, 1758 (Chiroptera: Noctilionidae) en Los Andes Sur del Ecuador}

Editado por /

Edited by:

Elisa Bonaccorso

Recibido /

Received:

09/07/2019

Aceptado /

Accepted:

28/10/2019

Publicado en línea

/ Published online:

20/02/2020

\section{Abstract}

The genus Noctilio includes two species which occur in elevation ranges that do not exceed $1000 \mathrm{~m}$ a.s.l. They have characteristic eating habits, which is why they are known as fishing bats. Their anatomy and shape of the face, as well as the coloration of the fur, make them very distinctive. In this work we report a record of an adult male of Noctilio leporinus at 3600 m elevation in Migüir locality near Cajas National Park in the Azuay province in the southern Andes of Ecuador. This is the first record for Noctilio leporinus in elevations that exceed 600 meters which makes it an unusual case.

Keywords: Cajas National Park, Cuenca, distribution range, coastal cities.

\section{Resumen}

El género Noctilio incluye dos especies que se encuentran distribuidas en rangos de elevación que no sobrepasan los 1000 m s.n.m. Tienen hábitos alimenticios muy característicos, por lo que son conocidos como murciélagos pescadores. Su anatomía y forma del rostro, así como la coloración del pelaje los hace muy distintivos. En este trabajo se da a conocer un registro de un macho adulto de Noctilio leporinus a $3600 \mathrm{~m}$ en la localidad de Migüir cerca del Parque Nacional Cajas en la provincia del Azuay en los Andes sur del Ecuador. Este registro es el primero para Noctilio leporinus en elevaciones que sobrepasan los $600 \mathrm{~m}$ lo que lo convierte en un caso inusual.

Palabras clave: Ciudades costeras, Cuenca, Parque Nacional Cajas, rango de distribución. 
The genus Noctilio has two species of Bulldog bats Noctilio albiventris Desmartes, 1818 (Lesser Bulldog Bat) and Noctilio leporinus Linnaeus, 1758 (Greater Bulldog Bat), and both are restricted to the lowlands associated with streams, bodies of water, and coastal marine ecosystems [1-2]. These species are restricted to the Americas from the east coast of Mexico to northern Argentina, including Cuba and the Lesser Antilles [3]. Both species are present in Ecuador; Noctilio albiventris commonly occurs in Amazonia up to $400 \mathrm{~m}$ a.s.l. and Noctilio leporinus occurs on the western and eastern slopes of the Andes mountain range up to elevations of $660 \mathrm{~m}$. The diet of both species includes aquatic insects and fish up to $12 \mathrm{~cm}$ in length [4-7]. These species have adaptations that make them easily recognizable. Some of these characteristics are: the snout and nose without excrescences, a projected nose pad, swollen lips and crests that give it a "bulldog" appearance, well developed feet and claws. The fur is striking reddish yellow, which differs from other species of bats, which are generally dark [7-9].

Here we report an adult male specimen of Noctilio leporinus found in February 2019 in the area of Migüir $\left(2.79^{\circ} \mathrm{S}, 79.28^{\circ} \mathrm{W}, 3600 \mathrm{~m}\right)$, near the union of the Migüir river with the Contra Hierba creek in Azuay province, south Ecuador (Fig. 1). The specimen was located inside a cottage used as a warehouse. The bat was perched on a table and showed a weak physical condition probably due to its low body temperature. The specimen was collected for its respective description and deposited in the Zoology Museum of Universidad del Azuay under the code MZUA-MA470.

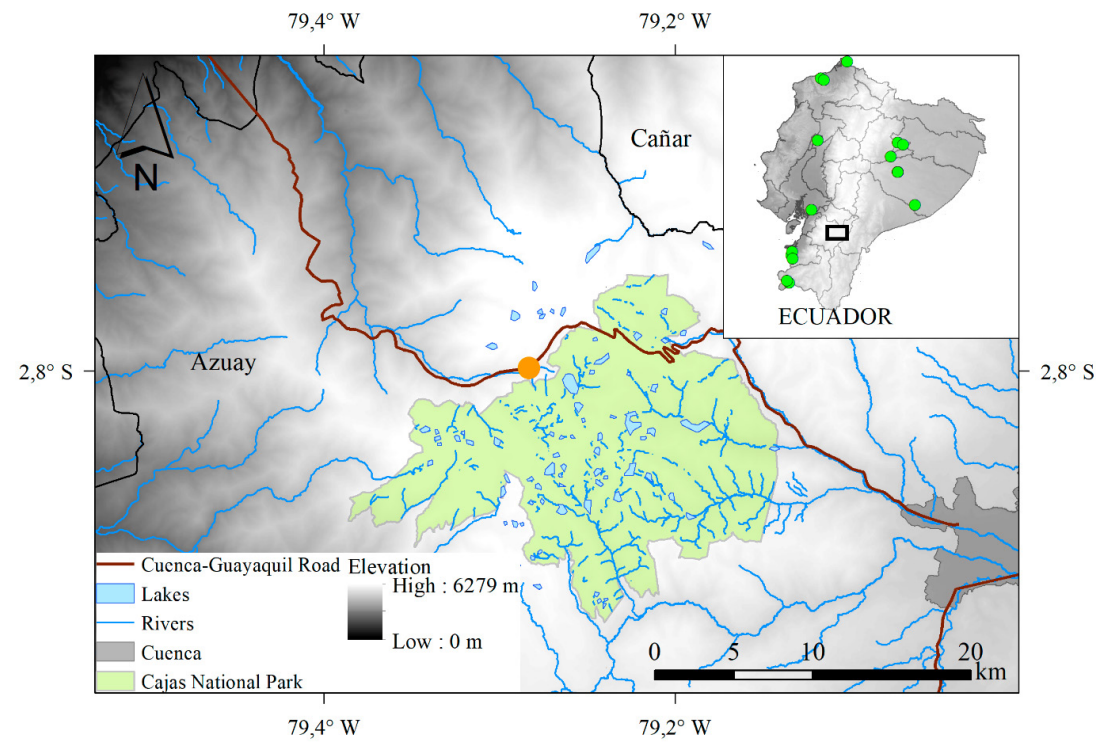

FIGURE 1. Record site of Noctilio leporinus in Migüir locality (orange circle), near Cajas National Park, Azuay Province, southern Ecuador. The green circles represent the literature localities taken from Albuja, Vallejo \& Boada and Brito et al. [4, 10-11]. 
The specimen presents reddish orange fur with a pale line on the back. Lips are swollen with a projected snout. The forearm is long $(87 \mathrm{~mm})$, feet with curved claws and an elongated calcar. (Table 1, Fig. 2). Sex and age were determined by presence of scrotal testicles. These characteristics correspond to the description of Noctilio leporinus according to Hood \& Jones, Albuja and Tirira $[4,7,9]$. The only similar species in Ecuador is Noctilio albiventris; however, this is smaller and the forearm reaches a maximum of $68.70 \mathrm{~mm}$, so this record undoubtedly corresponds to a specimen of Noctilio leporinus.

Unusual records in the distribution range of species are not frequent; however, they do arise in nature. Some records of species out of their ordinary distribution include: Peropteryx macrotis in the Andean highlands of Ecuador, Pseudalopex culpaeus below its common altitudinal range, Cardellina canadensis with a new locality in southern Ecuador and Nyctinomops macrotis in the inter-Andean valley of southern Ecuador [12-15]. These and other cases can be attributed to different factors such as: accidental transportation by a vehicle across the highways, vagrant individuals due to climatic factors, or temporal availability of resources in the area [12].

TABLE 1. Main measurements (mm) of an adult male of Noctilio leporinus recorded in Migüir, Azuay province, south Ecuador.

\begin{tabular}{|c|c|c|c|}
\hline Measurements & MZUA-MA470 & Albuja 1999 & Tirira 2017 \\
\hline HB & 83 & $82-100$ & $89-105$ \\
\hline TL & 21 & 30 & $26-35$ \\
\hline FT & 31 & $29-30$ & $25-35$ \\
\hline E & 27 & $29-34$ & $26-29$ \\
FA & 87 & $81-88.3$ & $75-88$ \\
\hline CA & 39 & & \\
\hline
\end{tabular}

$\mathrm{HB}=$ head and body, $\mathrm{TL}=$ tail length, $\mathrm{FT}=$ foot length, $\mathrm{E}=$ ear, $\mathrm{FA}=$ forearm, $\mathrm{CA}=$ calcaneus. Literature information from Albuja and Tirira $[4,7]$. 

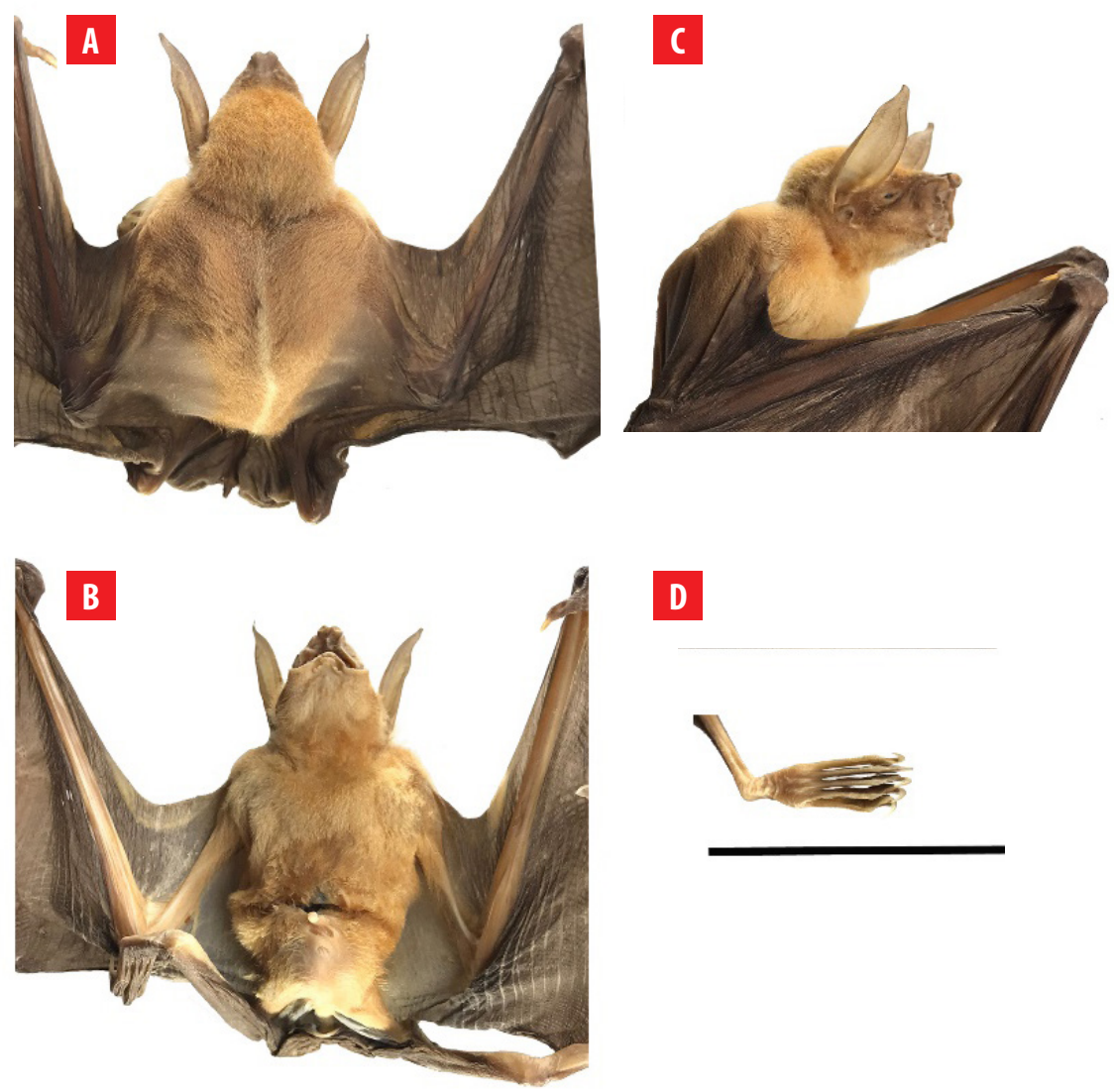

D

FIGURE 2. Specimen of Noctilio leporinus (MZUAMA470) recorded in Migüir, near Cajas National Park, Azuay Province, south Ecuador. A) dorsal view, B) ventral view, C) lateral view and D) right foot dorsal view. Scale bar $=5$

$\mathrm{cm}$.

In this sense, the presence of an individual of Noctilio leporinus in the high Andes in Ecuador at $3000 \mathrm{~m}$ above the common distribution may be a case of accidental transport by a vehicle $[12,16,17]$; the Cuenca-Guayaquil road is a highway transited by trucks that transport merchandise from coastal cities to Cuenca city. Finally, the altitudinal distribution of this species and the conditions in which the specimen was found do not support this as a new range in its distribution. However, the possibility of migration of this species cannot be completely ruled out, since within this group there are several migratory species such as Tadarida brasiliensis and Leptonycteris curasoae $[18,19]$. For this reason, further studies on the ecology of this species are required. 


\section{ACKNOWLEDGEMENTS}

This work was possible thanks to the support of the dean of research of the Universidad del Azuay, Jacinto Guillen. The Zoology Museum of the Universidad del Azuay is under the patent FAUS-UDA-Museo de Zoología-03-2018.

\section{AUTHORS' CONTRIBUTIONS}

Carlos Nivelo Villavicencio identified the specimen, wrote, and reviewed the document; Francisco Sánchez Karste reviewed the specimen and wrote the document; David C. Siddons wrote and reviewed the translation of the document; Javier Fernández de Córdova corroborated the specimen identification, wrote, and reviewed the document. 


\section{REFERENCES}

[1] Gardner, A. L. (2008). Family Noctilionidae. In A. L. Gardner (Ed.), Mammals of South America (pp. 384-388). Chicago, IL: University of Chicago Press.

[2] Bárquez, R., Pérez, S., Miller, B., \& Díaz, M. (2015). Noctilio leporinus. The IUCN Red List of Threatened Species 2015: e.T14830A22019554. doi: http://dx.doi.org/10.2305/IUCN.UK.2015-4.RLTS.T14830A22019554.en

[3] Emmons, L. H., \& Feer, F. (1997). Neotropical Rainforests Mammals: A field guide (2nd ed.). Chicago, IL: University of Chicago Press.

[4] Albuja, L. (1999). Murciélagos del Ecuador. Departamento de Ciencias Biológicas. Escuela Politécnica Nacional. 2nd Edición. Cicetrónic Cia.Ltda. Offset. Quito.

[5] Brooke, A. P. (1994). Diet of the fishing bat, Noctilio leporinus (Chiroptera: Noctilionidae). Journal of Mammology, 75(1), 212218. doi: https://doi.org/10.2307/1382253

[6] Bordignon, M. 0., \& Franca, A. (2002). Fish consumption by Noctilio leporinus (Linnaeus, 1758) in Guaratuba Bay, southern Brazil. Chiroptera Neotropical, 8, 148150.

[7] Tirira, D. G. (2017). Guía de campo de los mamíferos del Ecuador. Incluye los Islas Galapagos y la Zona Antártica Ecuatoriona. Publicación Especial, 11.

[8] Hood, C. S., \& Pitocchelli, J. (1983). Noctilio albiventris. Mammalian Species, (197), 1-5. Retrieved from: http://www. bio-nica.info/Mammalia/Noctilio_albiventris.pdf

[9] Hood, C. S., \& Jones, J. K. (1984). Noctilio leporinus. Mammalian Species, (216), 1-7. Retrieved from: http://www. bio-nica.info/Mammalia/Noctilio_leporinus.pdf

[10] Vallejo, A. F., \& Boada, C. (2018). Noctilio leporinus En: Brito, J., Camacho, M. A., Romero, V. Vallejo, A. F. (2018). Mamíferos del Ecuador. (Versión 2018.0) Museo de Zoología, Pontificia Universidad Católica del Ecuador. Recuperado el 30 de octubre de 2019 de: https://bioweb.bio/faunaweb/mammaliaweb/FichaEspecie/Noctilio\%20leporinus

[11] Brito, J., Garzón-Santomaro, C., MenaValenzuela, P., GonzálezRomero, D., \& MenaJaén, J. (Eds.). (2018). MAMífEROS DE LA PROVINCIA DE EL ORO: Una guía de identificación de especies de mamíferos del Páramo al Mar. GADPEOINABIO. Quito-Ecuador.

[12] Jarrin-V, P. (2003). An unusual record of Peropteryx macrotis (Chiroptera: Emballonuridae) in the Andean highlands of Ecuador. Mammalia, 67(4), 613-616. doi: https://doi.org/10.1515/mamm-2003-0421

[13] Ordóñez-Delgado, L., Vits, C., González, I., \& Valle, D. (2018). Registro altitudinal inusual de Zorro Andino Pseudalopex culpaeus (Carnívora: Canidae) en el sureste de Ecuador. ACI Avances en Ciencias e Ingenierías, 10(1). doi: https://doi. org/10.18272/aci.v10i1.862

[14] Ordóñez-Delgado, L., Reyes-Bueno, F., Orihuela-Torres, A., \& Armijos-0jeda, D. (2016). Registros inusuales de aves en la hoya de Loja, Andes sur del Ecuador. ACI Avances en Ciencias e Ingenierías, 8(14). doi: https://doi.org/10.18272/ aci.v8i14.276

[15] Sánchez-Karste, F., Nivelo-Villavicencio, C., Fernández de Córdova, J., \& Astudillo, P. X. (2017). New extension range of Nyctinomops macrotis Gray, 1840 (Chiroptera: Molossidae) in Southern Andes of Ecuador. Brazilian Journal of Biological Sciences, 4(7), 3-8. doi: https://dx.doi.org/10.21472/bjbs.040721

[16] Cancino, E. R., Myartseva, S. N., Agronomía, U. A. M., \& UAT, C. (2002). Distribución geográfica de animales. Revista de la Universidad Autonóma de Tamaulipas.

[17] Gomez, J. M., Fernández, A. M., González, C. D., \& González, A. (2009). Un polizón en un saco de patatas: transporte accidental de Mauremys leprosa desde Sevilla a Cantabria. Boletín de la Asociación Herpetológica Española, (20), 111 112. Recuperado de http://www.herpetologica.org/bahe/BAHE20_029_Cons07.pdf

[18] Villa, B. R. (1956). Tadarida brasiliensis mexicana (Saussure), el murciélago guanero, es una subespecie migratoria. Acta Zoológica Mexicana, 1(11), 1-11.

[19] Sánchez, F., \& Cadena, A. (1999). Migración de Leptonycteris curasoae (Chiroptera: Phyllostomidae) en las zonas áridas del norte de Colombia. Revista de la Academia Colombiana de Ciencias Exactas, Físicas y Naturales, 23, S683-S683. 